\title{
Wpływ akceptacji choroby na jakość życia pacjentów z cukrzycą typu 2
}

\section{Effect of disease acceptance on the quality of life of patients with type $\mathbf{2}$ diabetes}

\section{Streszczenie}

Wstęp. Cukrzyca typu 2 jest chorobą przewlekłą, rozwija się często bezobjawowo, nie wykazując problemów klinicznych, natomiast często po rozpoznaniu towarzyszą już jej powikłania mikronaczyniowe i makronaczyniowe. Przewlekła choroba zmienia obraz świata, przewartościowuje życie większości osób, które zmuszone są do zmiany swoich życiowych celów. W zależności od zaistniałej sytuacji każdy człowiek inaczej reaguje na chorobę. Jedni ludzie akceptują ten stan, inni nie mogą pogodzić się z faktem choroby.

Cel. Celem badań było wskazanie zależności między zaakceptowaniem przez pacjentów cukrzycy typu 2, a jakością ich życia. Jednocześnie na podstawie przeprowadzonych badań można ocenić przystosowanie się do życia z chorobą.

Materiał i metody. W badaniach wzięło udział 80 osób ze zdiagnozowaną cukrzycą typu 2. Byli to pacjenci hospitalizowani w Oddziale Chorób Wewnętrznych i zarejestrowani w Poradni Diabetologicznej Zespołu Opieki Zdrowotnej w Chełmnie. Jako narzędzie badawcze zastosowano Kwestionariusz Oceny Jakości Życia SF-36 oraz kwestionariusz AIS. Na przeprowadzenie badań uzyskano zgodę powyższej placówki oraz Komisji Bioetycznej.

Wyniki. Średni wartość punktowa jakości życia wyniosła wśród badanych - 78,64 punktu. Wynik ten wskazuje, że badane to grupa o przeciętnym poziomie jakości życia, na granicy poziomu wysokiego. Największy negatywny wpływ na poziom jakości życia badanych miało ogólne poczucie zdrowia. Ze wszystkich obszarów akceptacji choroby, najwyżej ocenili badani poczucie - myślę, że ludzie przebywający ze mną są często zakłopotani z powodu mojej choroby - średnia3,74 punktu oraz mój stan zdrowia sprawia, że nie czuję się człowiekiem pełnowartościowym - średnia 3,64 punktu.

Wnioski. 1. Pacjenci wykazujący wyższy stopień akceptacji lepiej funkcjonują w sferze emocjonalnej i fizycznej, a co za tym idzie mogą realizować się w sferze zawodowej oraz społecznej. 2. Pacjenci wykazujący wyższy stopień akceptacji choroby łatwiej przystosowali się do ograniczeń narzuconych przez chorobę. 3. Pacjenci wykazujący wyższy stopień akceptacji choroby czują się ludźmi pełnowartościowymi.

\section{Abstract}

Introduction. Type 2 diabetes is a chronic disease and its development is often asymptomatic, showing no clinical problems, but often after diagnosis it is already accompanied by the microvascular and macrovascular complications. A chronic disease changes the picture of the world, revalues the lives of 
most people who are forced to change their life goals. Depending on the situation, each person reacts differently to the illness. Some people accept this condition, others cannot accept the fact of the disease.

Aim. The aim of the study was to identify the relationship between the acceptance by patients with type 2 diabetes, and the quality of their lives. At the same time based on the studies carried out it is possible to evaluate one's adaptation to living with the disease.

Material and methods. The study included 80 patients diagnosed with type 2 diabetes. They were the patients hospitalized in the Department of Internal Medicine and registered in the Outpatient Diabetes Health Care Centre in Chełmno. As a research tool the Quality of Life Rating Questionnaire SF-36 and AIS questionnaire were applied. The study was approved by the aforementioned institutions and the Committee on Bioethics.

Results. The average point value of quality of life among the respondents was 78.64 points. This result indicates that the study group is a group with an average level of quality of life, on the border of the high level. The biggest negative impact on the quality of life of respondents came from a general feeling of health. Of all the areas of the disease acceptance, most respondents assessed the sense - I think people staying with me are often embarrassed because of my illness - average 3.74 point, and my state of health makes me not feel a fully fulfilled person - average 3.64 point.

Conclusions. 1. Patients indicating a higher degree of acceptance function better in emotional and physics pheresl, and thus may be realized in the professional and social sphere. 2. Patients exhibiting a higher degree of acceptance of the disease more easily adapted to the limitations imposed by the disease. 3 Patients showing a higher degree of acceptance of the disease feel fully-fulfilled as a person.

Słowa kluczowe: cukrzyca typu 2, jakość życia, akceptacja, pacjent

Key words: type 2 diabetes, quality of life, acceptance, patient

\section{Wstęp}

Cukrzyca typu 2 jest chorobą cywilizacyjną, przewlekłą, która często rozwija się podstępnie przez długie lata bez objawów somatycznych, a w momencie rozpoznania towarzyszą jej liczne powikłania mikronaczyniowe i makronaczyniowe. Przewlekłość procesu chorobowego odmienia postrzeganie świata, przewartościowuje życie większości pacjentów, którzy zmuszeni są do zmiany swoich ról życiowych. Każdy człowiek inaczej odnosi się do rozpoznania choroby. Niektórzy ludzie akceptują ten stan bez większych problemów, godząc się z diagnozą, natomiast inni nie mogą pogodzić się z faktem choroby. Osoby, które akceptują swoją chorobę, doświadczają mniej negatywnych emocji i chętniej współuczestniczą w procesie leczenia. U takich pacjentów możemy zaobserwować lepszą jakość życia z chorobą.

Holistyczna koncepcja opieki nad pacjentem powoduje wzmożone zainteresowanie się tematyką jakości życia osób z rozpoznaną chorobą przewlekłą, która stanowi wskaźnik jakości opieki. Zapożyczenie pojęcia „jakość życia” z nauk społecznych na grunt medycyny wynikało z zaprzeczenia tradycyjnych metod ewaluacji stanu zdrowia. Postęp technologii medycznej, cywilizacji oraz farmakologii zrodził nowe wyzwanie dla opieki medycznej, polegające nie tylko na wydłużaniu życia pacjentów, ale też na poprawie jego jakości. Aspekt ten jest szczególnie istotny w przypadku chorób przewlekłych, między innymi cukrzycy [1].

Według odniesienia do literatury, badanie jakości życia (QOL) chorych na cukrzycę powinno stanowić stałą składową opieki diabetologicznej, ponieważ cukrzyca jako przewlekła choroba metaboliczna z licznymi powikłaniami, powoduje wiele zaburzeń w sferze biologicznej, psychicznej i społecznej pacjenta. Gorszy stan kliniczny chorego obniża jakość jego życia [2,3]. Postawa pacjenta wobec choroby zależy od wielu elementów, do których między innymi należą: osobowość pacjenta, indywidualne skłonności do zachowań zdrowotnych, akceptacja choroby, sposoby radzenia sobie ze stresem, wsparcie społeczne [2]. Akceptacja choroby oznacza 
przyjęcie pozytywnej postawy wobec danej sytuacji, sprzyja mobilizacji sił pacjenta i umożliwia zapobieganiu obniżenia jakości życia w konsekwencji choroby przewlekłej[4,5].

Celem badań własnych było określenie poziomu akceptacji choroby oraz jej wpływu na jakość życia u pacjentów z cukrzycą typu 2.

\section{Materiał i metody}

Badania były prowadzone wśród pacjentów leczonych w Oddziale Chorób Wewnętrznych oraz zarejestrowanych w Poradni Diabetologicznej Zespołu Opieki Zdrowotnej w Chełmnie. Dane zbierano w okresie od 01.12.2015 roku do 01.04.2016 roku.

W badaniach wzięło udział 80 osób ze zdiagnozowaną cukrzycą typu 2. Pacjenci zostali poinformowani, że wyniki niniejszych badań zostaną wykorzystane do celów naukowych.

Zastosowano Kwestionariusz Oceny Jakości Życia SF-36 oraz kwestionariusz AIS. Pacjentom wraz z kwestionariuszem ankiety wręczano informację o anonimowości badania.

Najliczniejszą grupę stanowili respondenci w przedziale wiekowym: 41-50 lat (25\%) oraz 51-60 lat (26,3\%). Większość badanych stanowiły kobiety (86,3\%), mieszkańcy miasta (70\%). Największą grupę stanowili badani ze średnim wykształceniem $(43,8 \%)$ oraz legitymujące się wyższym wykształceniem (35\%). W grupie respondentów przeważały osoby aktywne zawodowo (57,5\%). Zdecydowaną większość badanych stanowiły osoby chorujące do 5 lat (57,5\% pacjentów , 6-15 lat (26\% osób), powyżej 15 lat (16,3\% respondentów).

\section{Wyniki}

W badaniu wykorzystano kwestionariusz SF - 36, umożliwiający subiektywną ocenę stanu zdrowia. W pierwszej tabeli przedstawiono średni wynik jakości życia, stanowiący odniesienie do dalszych badań. Przedstawione w pracy wyniki stanowią jedynie element przeprowadzonych pierwotnie badań.

Tabela 1. Średni wynik jakości życia.

\begin{tabular}{|c|c|c|c|c|c|c|c|c|c|}
\hline $\mathrm{N}$ & Średnia & $\mathrm{SD}$ & $\begin{array}{c}\text { Ufność } \\
-95,0 \%\end{array}$ & $\begin{array}{c}\text { Ufność } \\
+95,0 \%\end{array}$ & minimum & maksimum & Q25 & mediana & Q75 \\
\hline 80 & 78,6 & 31,5 & 71,6 & 85,6 & 26,0 & 149,0 & 52,0 & 80,0 & 102,5 \\
\hline
\end{tabular}

Źródło: opracowanie własne

Średni wartość punktowa jakości życia wyniosła wśród badanych - 78,64 punktu. Wynik ten wskazuje, że badane to grupa o przeciętnym poziomie jakości życia, na granicy poziomu wysokiego.

Tabela 2 i rycina 2 prezentuje poziom jakości życia respondentów.

Tabela 2. Poziom jakości życia badanych.

\begin{tabular}{|c|c|c|}
\hline poziom & liczba & $\%$ \\
\hline niski & 14 & 17,5 \\
\hline przeciętny & 30 & 37,5 \\
\hline wysoki & 36 & 45,0 \\
\hline
\end{tabular}




\begin{tabular}{|l|l|l|}
\hline Razem & 80 & 100,0 \\
\hline
\end{tabular}

Źródło: opracowanie własne

Rycina 1. Rozkład poziomu jakości życia badanych.

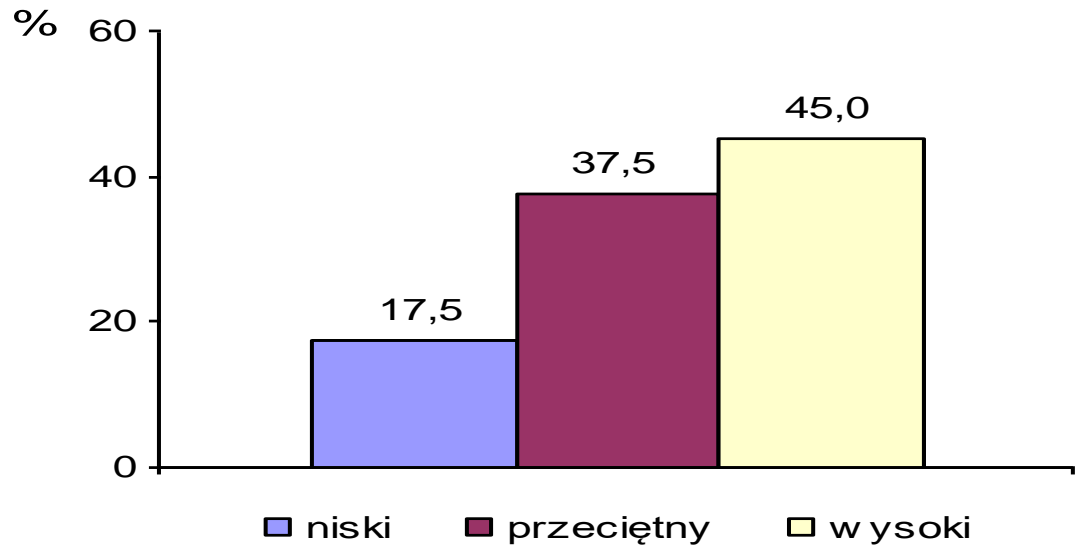

Źródło: opracowanie własne

Najwięcej badanych prezentowało wysoki poziom jakości życia - 36 osób $(45,0 \%)$. Najmniejszy odsetek respondentów oceniał swój poziom jakości życia jako niski - 14 osób $(17,5 \%)$.

W tabeli 3 przedstawiono wyniki oceny poszczególnych podskal jakości życia respondentów.

Tabela 3. Średnie wyniki podskal jakości życia badanych.

\begin{tabular}{|l|c|c|c|c|}
\hline Pozycja & Średnia & SD & $\begin{array}{c}\text { Wartość } \\
\text { maksymalna }\end{array}$ & Wskaźnik \% \\
\hline funkcjonowanie fizyczne (PF) & 19,30 & 14,949 & 50 & 38,6 \\
\hline ograniczenia w pełnieniu ról (RP) & 10,94 & 6,940 & 20 & 54,7 \\
\hline dolegliwości bólowe (BP) & 3,80 & 2,021 & 9 & 42,2 \\
\hline ogólne poczucie zdrowia (GH) & 11,38 & 2,901 & 20 & 56,9 \\
\hline witalność (VT) & 9,83 & 2,984 & 20 & 49,1 \\
\hline funkcjonowanie społeczne (SF) & 3,18 & 1,465 & 8 & 39,7 \\
\hline $\begin{array}{l}\text { ograniczenie w pełnieniu ról } \\
\text { wynikających z problemów } \\
\text { emocjonalnych (RE) }\end{array}$ & 7,81 & 6,051 & 15 & 52,1 \\
\hline poczucie zdrowia psychicznego (MH) & 9,89 & 3,190 & 25 & 39,6 \\
\hline
\end{tabular}

Źródło: opracowanie własne

Największy negatywny wpływ na poziom jakości życia badanych miało ogólne poczucie zdrowia (GH). Wskaźnik wyniósł 56,9\% negatywnych punktów możliwych do osiągnięcia. 
W dalszej kolejności były to ograniczenia w pełnieniu ról (RP) - 54,7\% oraz ograniczenie w pełnieniu ról wynikających z problemów emocjonalnych (RE) - 52,1\%. W najmniejszym stopniu taki wpływ dotyczył funkcjonowania społeczne (SF) - 39,7\% poczucia zdrowia psychicznego (MH) - 42,2\% oraz funkcjonowania fizycznego (PF) - 38,6\%.

Drugim narzędziem wykorzystanym w badaniu stanowiła Skala Akceptacji Choroby (AIS). W przypadku niniejszych badań analizowano akceptację choroby wśród pacjentów z rozpoznaną cukrzycą typu 2 .

W tabeli 4 przedstawiono średnie wyniki ocen prezentowanych przez badanych w AIS.

Tabela 4. Średnie oceny utrudnień wynikających $z$ choroby przez badanych wg kwestionariusza AIS.

\begin{tabular}{|c|c|c|c|c|c|c|c|c|}
\hline L.p. & Pozycja & $\mathrm{N}$ & 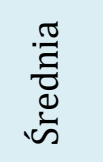 & SD & 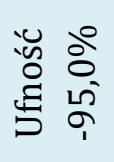 & 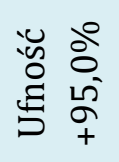 & 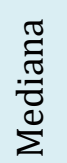 & 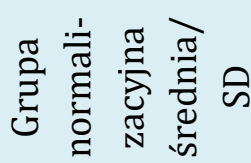 \\
\hline 1 & \begin{tabular}{|lrr} 
mam & kłopoty & $\mathrm{z}$ \\
przystosowaniem & się \\
do & ograniczeń \\
narzuconych & przez \\
chorobę &
\end{tabular} & 80 & 3,00 & 1,147 & 2,74 & 3,26 & 1,0 & $2,63 / 1,32$ \\
\hline 2 & 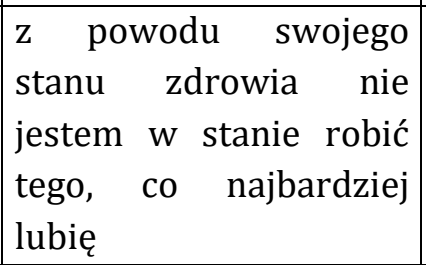 & 80 & 3,15 & 1,148 & 2,89 & 3,41 & 1,0 & $2,45 / 1,37$ \\
\hline 3 & $\begin{array}{|lcr|}\text { choroba } & \text { sprawia, } & \text { że } \\
\text { czasem } & \text { czuję } & \text { się } \\
\text { niepotrzebny } & \end{array}$ & 80 & 3,18 & 1,178 & 2,91 & 3,44 & 1,0 & $3,29 / 1,44$ \\
\hline 4 & 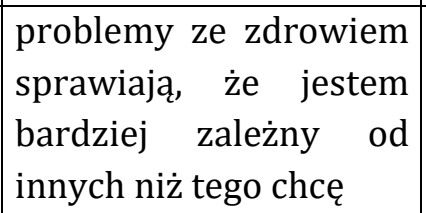 & 80 & 3,26 & 1,280 & 2,98 & 3,55 & 1,0 & $2,59 / 1,32$ \\
\hline 5 & $\begin{array}{|lrr|}\text { choroba } & \text { sprawia, } & \text { że } \\
\text { jestem } & \text { ciężarem } & \text { dla } \\
\text { swojej } & \text { rodziny } & \mathrm{i} \\
\text { przyjaciół } & & \end{array}$ & 80 & 3,64 & 1,193 & 3,37 & 3,90 & 1,0 & $2,36 / 1,37$ \\
\hline 6 & $\begin{array}{l}\text { mój stan zdrowia } \\
\text { sprawia, że nie czuję się } \\
\text { człowiekiem } \\
\text { pełnowartościowym }\end{array}$ & 80 & 3,64 & 1,150 & 3,38 & 3,89 & 1,0 & $3,31 / 1,38$ \\
\hline 7 & $\begin{array}{l}\text { nigdy nie będę } \\
\text { samowystarczalnym w } \\
\text { takim stopniu, } \\
\text { chciałbym być jakim }\end{array}$ & 80 & 3,18 & 1,123 & 2,93 & 3,42 & 1,0 & $3,81 / 1,51$ \\
\hline 8 & $\begin{array}{|lrr|}\text { myślę, } & \text { że } & \text { ludzie } \\
\text { przebywający } & \text { ze } & \text { mną } \\
\text { są } & \text { często } & \text { zakłopotani } \\
\end{array}$ & 80 & 3,74 & 1,209 & 3,47 & 4,01 & 1,0 & $3,01 / 1,45$ \\
\hline
\end{tabular}




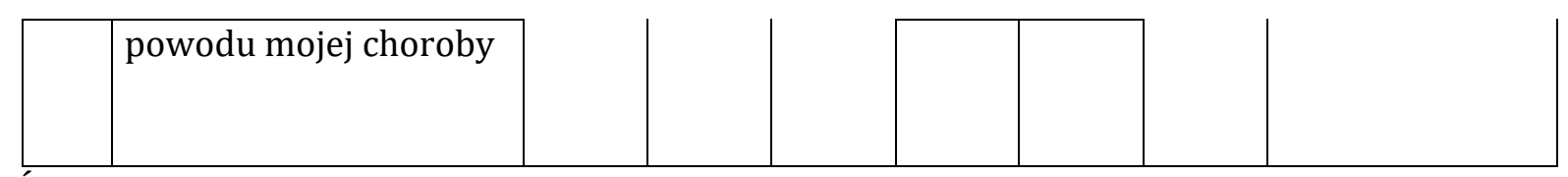

Źródło: opracowanie własne

Rycina 2 prezentuje średnie wyniki ocen akceptacji choroby przez badanych.

Rycina 2. Rozkład średnich ocen utrudnień wynikających z choroby przez badanych wg kwestionariusza AIS.

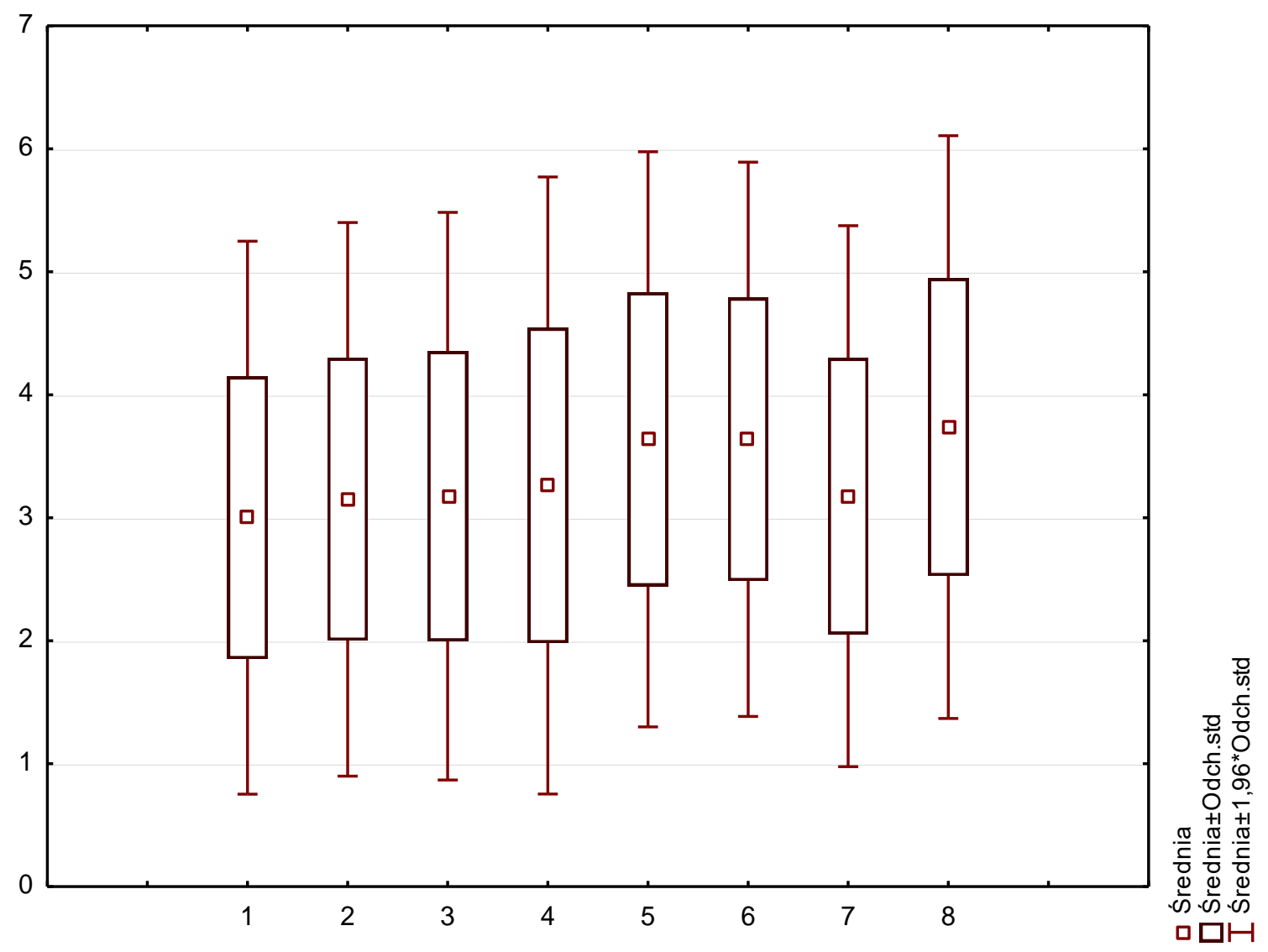

Źródło: opracowanie własne

Ze wszystkich rozpatrywanych obszarów akceptacji choroby, najwyżej respondenci ocenili poczucie „myślę, że ludzie przebywający ze mną są często zakłopotani z powodu mojej choroby” - średnia 3,74 punktu oraz „mój stan zdrowia sprawia, że nie czuję się człowiekiem pełnowartościowym” - średnia 3,64 punktu. Najniżej natomiast ze wszystkich pozycji oceniono poczucie: „z powodu swojego stanu zdrowia nie jestem w stanie robić tego, co najbardziej lubię” - średnia 3,15 punktu oraz „mam kłopoty z przystosowaniem się do ograniczeń narzuconych przez chorobę" - średnia 3,0. Nadmienić należy, że w porównaniu z wynikami grupy normalizacyjnej, badani uzyskali w każdym z aspektów akceptacji choroby z wyjątkiem pozycji: „choroba sprawia, że czasem czuję się niepotrzebny” - średnia 3,0 punktu oraz: „nigdy nie będę samowystarczalnym w takim, w jakim chciałbym być" - średnia 7,0 punktu. 


\section{Dyskusja}

Przeprowadzenie badań własnych oraz ich analiza pozwoliły ocenić wpływ akceptacji choroby przewlekłej jaką jest cukrzyca typu $2 \mathrm{w}$ odniesieniu do jakości życia pacjentów. Cukrzyca stanowi współcześnie jedną z najczęściej rozpoznawanych chorób metabolicznych.

Wielu naukowców, analizując kwestie jakości życia, wskazuje subiektywny aspekt tych badań, który jest obrazem sytuacji, emocji i odczuć pacjenta. Ocena dotyczy jakości życia w odniesieniu do stanu szeroko rozumianego zdrowia: dobrostanu fizycznego, psychicznego i socjalnego. Badaniu poddawany jest stopień trudności w czynnościach życia codziennego, w tym w pracy, w czasie wypoczynku i prowadzeniu domu oraz wynikające z nich problemy w relacjach z rodziną, przyjaciółmi i społeczeństwem oraz stopień satysfakcji osiąganej w danej dziedzinie życia.

Postawa pacjenta wobec choroby zależy od wielu elementów, do których należą: osobowość pacjenta, indywidualne skłonności do zachowań zdrowotnych, akceptacja choroby, sposoby radzenia sobie ze stresem, wsparcie społeczne. Akceptacja choroby oznacza przyjęcie pozytywnej postawy wobec danej sytuacji, sprzyja mobilizacji sił pacjenta i umożliwia zapobieganiu obniżenia jakości życia w konsekwencji choroby przewlekłej.

K. Kurowska i B. Lach w latach 2010 - 2011 przeprowadziły badania w grupie 77 chorych na cukrzycę typu 2, przebywających w Klinice Endokrynologii i Diabetologii Szpitala Uniwersyteckiego im. A. Jurasza w Bydgoszczy. W badaniach wykorzystano skalę akceptacji choroby (AIS) w adaptacji Juczyńskiego oraz kwestionariusz CISS, służący pomiarowi radzenia sobie ze stresem $\mathrm{w}$ sytuacjach trudnych. Badanie wykazało przeciętny stopień akceptacji choroby - badana grupa uzyskała 25,16 punktów. Wśród pacjentów zaobserwowano wystąpienie wszystkich stylów radzenia sobie ze stresem. Najczęściej był to styl zadaniowy. W badaniach wskazano, ze istnieje związek między stopniem przystosowania się do choroby a stylami radzenia sobie ze stresem. Akceptacja choroby malała wraz ze wzrostem stylu skoncentrowanego na emocjach [6].

Badania dotyczące akceptacji choroby przeprowadzono również wśród pacjentów Przychodni Diabetologicznych Wojewódzkiego Centrum Medycznego i Wojewódzkiego Szpitala w Opolu. Badanie dotyczyło 98 chorych, wśród których znajdowały się osoby z cukrzycą typu 2, typu 1, typu LADA, cukrzycą ciążową oraz wtórną. Brak wiedzy na temat typu choroby wskazało $10 \%$ badanych. Średnia liczby punktów w skali AIS wśród wszystkich badanych wynosiła 29 pkt. Ponad połowa respondentów (57\%) akceptowała swoją chorobę na poziomie wysokim. Można zatem przyjąć, że poziom jakości życia i subiektywnej oceny zdrowia pacjenta zależy od stopnia akceptacji cukrzycy. Akceptacja choroby zależy od takich czynników jak: płeć, wiek, wartość wskaźników zdrowotnych, przebieg cukrzycy oraz zastosowana farmakoterapia. Wyższy stopień akceptacji choroby wpływa na wyższą ocenę jakości życia i zdrowia pacjenta [7].

W latach 2010-2011 badanie przeprowadzono w grupie 100 osób chorych na cukrzycę typu 1 i 2. Badanie przeprowadzono wśród pacjentów Oddziału Wewnętrznego Szpitala Wojewódzkiego w Bełchatowie i leczonych w Klinice Diabetologii i Chorób Metabolicznych w Szpitalu Klinicznym w Łodzi. W badaniu zastosowano kwestionariusz ADDQoL, autorstwa Clare Bradley. Wykazano, że cukrzyca niezależnie od jej typu w sposób znaczący wpływa na pogorszenie ogólnej jakości życia. Badani wiążą ten fakt $\mathrm{z}$ wiekiem, w którym rozpoznano cukrzycę (im młodszy wiek, tym gorsza jakość życia). Wykazano również, że jakość życia pogarsza się w miarę trwania choroby [8].

Wyniki badania własnego przeprowadzonego wśród pacjentów Oddziału Chorób Wewnętrznych oraz Poradni Diabetologicznej w Zespole Opieki Zdrowotnej w Chełmnie wskazały, że średnia jakości życia wyniosła 78,64 pkt, co oznacza przeciętny poziom na granicy 
poziomu wysokiego. Wyższa jakość życia częściej dotyczyła kobiet (46,4\%). Połowa badanych (50\% respondentów) preferuje przeciętny poziom akceptacji choroby, a 42,5\% poziom wysoki. Średnia akceptacji choroby wyniosła dla badanej grupy 26,78 pkt. Wyższy wynik uzyskały kobiety w przedziale wiekowym do 40 lat i 51-60 lat, zamieszkałe w mieście z wykształceniem wyższym. Badania wykazały, że akceptacja choroby ma istotny wpływ na jakość życia z przewlekłą chorobą. Pacjenci akceptując swoją chorobę lepiej funkcjonują fizycznie, emocjonalnie oraz w sferze zawodowej.

\section{Wnioski}

Akceptacja choroby ma istotny wpływ na jakość życia pacjentów z cukrzycą jako chorobą przewlekłą. Ankietowani pacjenci Oddziału Wewnętrznego i Poradni Diabetologicznej potwierdzili postawioną hipotezę: jakość życia chorych z cukrzycą typu 2 zależy od stopnia akceptacji choroby. Wyższy stopień akceptacji choroby określał wyższą jakość życia pacjentów. Przekłada się to bezpośrednio na funkcjonowanie w sferze biologicznej, psychicznej, społecznej i zawodowej chorych. Pacjent akceptując chorobę wykazuje lepsze przystosowanie się do życia z cukrzycą typu 2 oraz wykazuje lepszą jakość życia z chorobą.

\section{Zalecenia dla praktyki pielęgniarskiej}

Przeprowadzone badania dają możliwość wykorzystania wyników bezpośrednio w praktyce pielęgniarskiej w odniesieniu do pacjentów z cukrzycą typu 2. Mogą stanowić istotny element projektowania holistycznego planu opieki wobec pacjenta chorującego przewlekle.

\section{Bibliografia / Bibliography:}

1. Dudzińska M., Tarach J., Nowakowski A. Pomiar jakości życia zależnej od zdrowia w cukrzycy. Diabetologia Praktyczna. 2011;12:56-64.

2. Pietrzykowska E., Zozulińska D., Wierusz-Wysocka B. Jakość życia chorych na cukrzycę. Pol. Merkuriusz Lek. 2007;XXIII(136):311-314.

3. Lewko J., Krajewska-Kułak E. Wielowymiarowa ocena jakości życia chorych na cukrzycę. Pol. Merkuriusz Lek. 2010;XXVIII(168):486-489.

4. Krajewska-Kułak E. Akceptacja sytuacji związanej ze stanem zdrowia przez pacjentki oddziału patologii ciąży i położniczego. Ginekologia Praktyczna. 2010:31-35.

5. Basińska M., Zalewska-Rydzkowska D., Wolańska P., Junik R. Dyspozycyjny optymizm a akceptacja choroby w grupie osób z chorobą Gravesa-Basedowa. Endokrynologia Polska. 2008;59:23-28.

6. Kurowska K., Lach B. Akceptacja choroby i sposoby radzenia sobie ze stresem u chorych na cukrzycę typu 2. Diabetologia Praktyczna. 2011;12:113-119.

7. Kurpas D., Czech T. Akceptacja choroby pacjentów z cukrzycą oraz jej wpływ na jakość życia i subiektywną ocenę zdrowia. Family Medicine \& Primary Care Review. 2012;383-388.

8. Glińska J., Skupińska A., Lewandowska M. Czynniki demograficzne a ogólna jakość życia chorych z cukrzycą typu 1 i 2. Problemy Pielęgniarstwa. 2012;20:279-288. 